\title{
A STUDY OF EFL STUDENTS' AWARENESS ON APOLOGY THROUGH CROSS CULTURAL LEARNING ACTIVITIES
}

\author{
Ardiyani Widya Permatasaria \\ Sebelas Maret University Surakarta, ardiyaniwidya@gmail.com \\ Diah Kristina ${ }^{b}$ \\ Sebelas Maret University Surakarta, kristina_diah@yahoo.com \\ Sumardic \\ Sebelas Maret University Surakarta, arif_sumardi74@yahoo.co.id
}

\begin{abstract}
This study was aimed at exploring what types of cross cultural learning activities used that contribute to EFL students' awareness on apology function, and how the process occurred at an EFL tertiary level. The data analyzed in this study were collected in Satya Wacana Christian University and Sebelas Maret University. The study was a mixed method in nature using a questionnaire and interview adapted from previous studies. The quantitative data was obtained from six Indonesian EFL students using Discourse Completion Tasks Questionnaires (DCTQ), while the qualitative data obtained from individual interviews carried out with six EFL students. The results showed that there were group discussion and role playing used as cross cultural learning activities which contributed to EFL students' awareness on apology functions. Another finding also indicated the use of apology strategies performing those two learning activities. It was unveiled that that EFL students employed numerous apology strategies that they were well aware of how to use adequate apology forms to meet the requirement of certain situations and relationships, and that they felt the need for explaining and avoiding interpretation of their responses as an apology.
\end{abstract}

Keywords: EFL students, awareness on apology, cross cultural learning activities 


\section{Permatasari et al., A Study of EFL Students...}

\section{INTRODUCTION}

There is a required course called Cross Cultural Understanding which is conducted to enhance students' overall English proficiency by focusing on developing students' writing, speaking, reading and listening skills (Zacharias, 2012). In English language teaching of English Department, Cross Cultural Understanding (CCU) course is a required course in a four-year pre-service program of an English Department in the Faculty of Language and Literature, in Indonesia. On the other hand, problems arise from the lack of cross-cultural awareness such as verbal communication, postures, mimics, another ways of behavior, and speech acts can cause miscommunication (Cakir, 2006, p.2).

In the pre-interview, the researcher has found informal findings that the participants are more aware of using the speech acts in the daily life communication. First case, a student who ever enrolled in student exchange when she was in her senior high school found that her classmates who comes from different nationalities did not know others cultures. Moreover, for saying sorry, she felt that their classmates did not really feel sorry for their mistakes for they did the same mistakes over again. For example, when they were joking and started to make stereotype by labeling their race. In this case, when she came back to Indonesia, she felt that implementing CCU based learning activity with speech act theory topic really helps to overcome similar problems she ever faced. Second case, a student who went abroad for vacation found that the degree of speech acts is different in each language and it needs adjustments and familiarization. For apology forms he found quite difficult for his to adjust within the beginning. He used to say "sorry" alot to people which is older than him. In fact, he knew that it is better to say "I do apologize". Thus, he felt that as EFL learners, we do not only have to acquire grammatical theories but also pragmatic theories in this case apology forms.

By noticing in the pre-interview and the topic selection, the researcher assumes that there are some significances of selecting the topic. First, there is a theoretical consideration that there is none of concrete data of this research for there are only theories about enhancing cross cultural understanding based learning activities and the importance of implementing speech act 
awareness (Lado, 1963, p. 110; Chastain, 1988). Moreover, for practical consideration the EFL students or learners' acquisition in how people act to certain situations, the way people speak and behave are enhanced. At last, the researcher curiosity is even deeper because of the lack of studies focusing on speech act awareness where English is a foreign language.

Some relevant studies conducted in the foreign language settings which focused on CCU based learning activity were firstly Zaharias, 2012 entitled EFL Students' Understanding of Their Multilingual English Identities and the findings were many of the participants negotiated their identities based on a core identity derived from their assumed first language culture. Then, Zayed, 2014 entitled Jordanian EFL teachers' and students' practice of speech acts in the classroom with the findings EFL teachers' and students had no proper practice of any of the speech acts although the teachers practiced the speech acts of greeting, request, and thanking better than the speech acts of apology and compliment and the students practiced the speech act of greeting better than the other speech acts. At last, Qorina Dwi 2012 conducted a study on realization of apology strategies by English Department Students of Pekalongan University who investigate the development strategies from the lowest to the highest semester students, and to explain how the pragmatic transfer interferes the apology strategies used by English Department students of Pekalongan University. The findings reveal that an explicit expression of apology, in particular, the strategy of expressing regret, is the most frequent apology strategy.

Studies focusing on CCU based learning activity in EFL context are even rarer. Knowing that EFL contexts are merely varied with regard to the intensity of English learning (i.e. hours per week), the availability of teaching materials, the relative importance of English in the society, and the purpose of learning English (Block, 2007 as cited in Zacharias, 2012, p. 234). Thus, the need of a study focusing on enhancing speech act awareness .

\section{OBJECTIVES}

Cross cultural Understanding for Indonesian EFL students is taught in English department as pre-requirement course. In 


\section{Permatasari et al., A Study of EFL Students...}

general, Indonesian students have to pass certain courses to be able to take Cross Cultural Understanding course. Nonetheless, the teaching and learning situation in Indonesia focuses more on linguistic competence. As a result, in real-life situation, Indonesian students often fail to communicate effectively with same Indonesian students from vary ethniticities or even foreigners using English in certain situations. To avoid misunderstanding between the speaker and the hearer and to achieve communication goal, specifically when the speaker and the hearer are from different cultures and ethnicities or countries is by knowing the meaning behind words. In this case, politeness plays a main role to avoid communication offense. The fact that there are many kinds of politeness concepts accross cultures in the world, studying apology functions and strategies through cross cultural learning activities will meet EFL students' needs in raising their awareness. This study may highlight two kinds of CCU learning activities and how these two learning activities play as a big role in raising EFL students' awareness on apology functions.

This study aims at explaining and providing evidence on to what extent CCU based learning activities contribute toward EFL students' awareness on apology functions. The result of the study aims at providing EFL learners or reasearchers or teachers with information that help to improve both competence: linguistic and pragmatic. At last, the study contributes to pragmatic-teaching in EFL research.

\section{LITERATURE REVIEW}

\section{a) CCU Based Learning Activity in ESL Context}

Researchers conducted some studies on CCU based learning activities in ESL context with some findings as below:

1. Mizne thesis project (1997) showed the solution of facing problems of ESL students toward lack of sociolinguistic competence which comes from lack of cross-cultural understanding of ESL students and leads to misunderstandings between the speech participants and then can cause serious breakdowns in communication by creating a teaching module 
(cross-cultural differences) which were proved to enhance ESL students' cultural and pragmatic awareness.

2. Youssef's research (2009) showed the students were better able to participate and express their ability and knowledge in the target language and had improved motivation by given crosscultural activity "Sister School Project" and the implementation of self-evaluation.

3. Fadeeva and Kalinin (2012) showed that ESL students 'crosscultural communication' is understood as adequate mutual understanding of participants of the communication belonging to different national cultures.

\section{b) CCU Based Learning Activities in EFL Context}

Researchers conducted some studies on CCU based learning activities in EFL context with some findings as below:

1. Lee (2000) showed that teachers have to have an ability to mediate the local and target culture and in line with openmindness and sensitivity to cross-cultural differences, should be raised in EFL classrooms.

2. Cakir (2006) showed that firstly developing cultural awareness in the classroom is important for teachers help students distinguish between the cultural norms, beliefs, or habits of the majority within the speech community, secondly development of an awareness of sociocultural and sociolinguistic differences which might exist in the students' first and foreign language prevent unintended pragmatic failure and breakdown in communication and the last studying English does not change students' identity and students implement teachers' theories to use English well.

3. Dai (2011) found that teachers should facilitate students' learning materials by implementing cross-cultural based learning activity and connecting with students' interests.

In the field of pragmatic, apology function attracted more attentions than other speech acts (Brown, 1987 as cited in Raed \& Mohamad, 2016, p. 33). The following are the indicators for EFL students who are aware of apologies:

1. EFL learners are able to realize and differentiate the use of appropriate realization pattern; 


\section{Permatasari et al., A Study of EFL Students...}

2. EFL learners have to be able to and aware of the intensification devices such as "very", "terribly", and "really" (Eslami Rasekh \& Mardani, 2010);

3. EFL learners are able to understand their positions. The recognition as apology makers toward the degree at the offence, the power of the addressee over the addressor, and the social distance (Brown \& Levinson, 1987);

4. EFL learners are able to maintain good relations between others (the participants of the speech) (Holmes, 1990);

5. EFL learners have to be able to understand and know the difference of expression "sorry" and "I apologize" and intensifiers like "very" and "really" (Olshtain \& Cohen (1983); Olshtain (1989);

6. EFL learners have to be able to interpret, give and respond in apologizing appropriately to build friendly relationships with native and non-native speakers especially when they encounter English speaking countries or working field (Wolfson, 1983).

Many researchers conducted studies to prove failure or success of awareness on speech acts functions from EFL students' perspectives, some studies can be summarized as follows:

1. Zhao \& Throssell (2011) found that Chinese EFL learners, even though possessing good mastery of English grammar and vocabulary, still fail to make use of appropriate speech in their communication with native speakers of English.

2. Wijayanto (2013) stated that Javanese learners of English commonly initiate refusals with an apology.

3. Zayed (2014) revealed that only one EFL teacher and one Jordanian EFL student in the first grade practiced the form 'an expression of an apology' particularly the word 'sorry; once.

4. Abolfathiasl and Abdullah (2015) Iranian EFL learners showed their consciousness-raising improved by performing and responding of making suggestions function of speech act.

5. Kurdghelashvili (2015) Georgian EFL students' were failed in term of their knowledge regarding politeness strategies in English communication for the speech acts functions only use by the teacher not the students in the classroom interactions.

Reviewing related studies related to cross cultural understanding-based learning activities from ESL and EFL context 
and speech act awareness of EFL learners leads a gap from previous researches. On the other hands, there are alot of studies on cross cultural understanding-based learning activities viewed from sociolinguistic competence, while there are few of cross cultural understanding studies from pragmatic point of view, speech act awareness. Whereas the study of cross cultural understanding requires to be analyzed deeper from both perspectives in order to give a better understanding on this term and a factual implementation toward learners, EFL learners. Therefore, the novelty of this study gives an additional analysis toward cross cultural understanding-based learning activities from the perspective of speech act awareness by enhancing speech act awareness on apology of EFL learners. Not only reviews the implementation of cross cultural understanding-based learning activities in EFL context, this study also explains and describes to what extent CCU based learning activities contribute toward the EFL students' awareness of speech acts and why the teaching of cross cultural understanding raises the speech act awareness of EFL students. It suggests teachers, lecturers, learners especially EFL learners to be more aware while performing speech acts functions through CCU based learning activities since it is implemented by some constraints.

\section{RESEARCH METHOD}

Six English Department students (who already passed CCU course) were chosen from private university in Salatiga and state university in Surakarta, Solo. To collect considerable information and get reliable data, the study analyzed one questionnaire (Discourse Completion Task Questionnaire) DCTQ and one interview with twelve participants. Before conducting actual study, the questionnaire and the interview were piloted and validated.

Discourse completion task questionnaire is regarded as an effective research instrument (Beebe \& Cummings, 1996, p. 66 as cited in Raed and Mohammad, 2016, p. 34). In the present study, the DCTQ consisted of six parts: the first one contained about Cross Cultural Understanding, the second part contained about speech acts, the next part contained about speech acts awareness, 


\section{Permatasari et al., A Study of EFL Students...}

the fourth part was about Cross-Cultural Understanding and speech acts awareness, the fifth part was about two situations from apology functions and the last part contained about background information of the participants.

The interviews are conducted in the learners' mother tongue (Bahasa Indonesia) and English, although most respondents preferred to use English. Each interview lasted between 15 and 20 minutes. The interviews are semi-structured (Merriam, 1998, P. 73). All the interviews are audio-taped and later transcribed for further analysis. These transcripts are then analyzed according to predetermined similar categories found in the questionnaire namely CCU understanding, CCU based learning activities, types of speech acts, speech act awareness

\section{FINDINGS AND DISCUSSION}

A. Group discussion for apology function as one of CCU learning activities viewed from communication strategies

Apology performed by EFL students from CCU learning activity showed that group discussion as the highest choice from the questionnaire and the interview done with them. Group discussion has $45 \%$ of other CCU learning activities, role play has $35 \%$, response journals has $10 \%$ and others like movie review, presentation and culture festival has $5 \%$. Then, the result was presented in the following chart and explanations were provided accordingly.

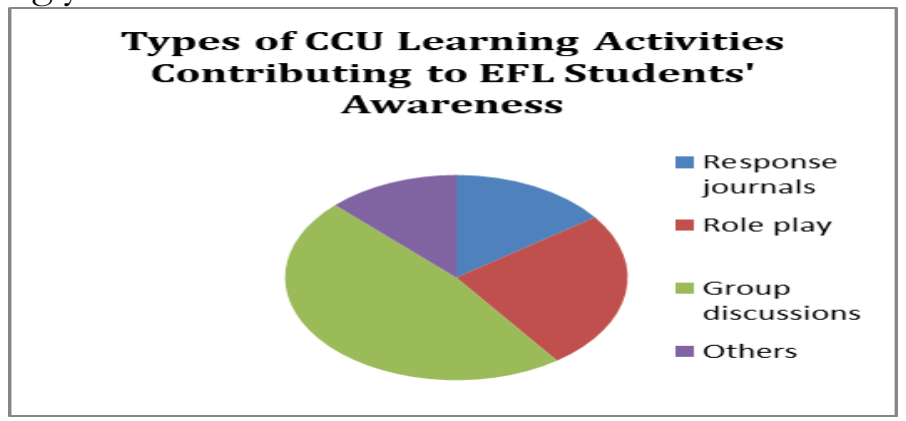

Chart 4.2 types of CCU learning activities that contribute EFL students' awareness

Talking about group discussions, it can be developed in the language classroom for pragmatic development to be specific raising EFL students' awareness on apology function. Kasper (1997) identified two types of activities. First, activities can focus 
on raising students' pragmatic awareness, or second, on tasks which provide opportunities for student to actually practice communication.

In this case, EFL students are provided with CCU learning activity in form of group discussion which raises their awareness on those two functions. As a leading discussion, the lecturer gave a picture which showed people were queuing in a movie theater and one person felt that his leg was stepped by another person as below:

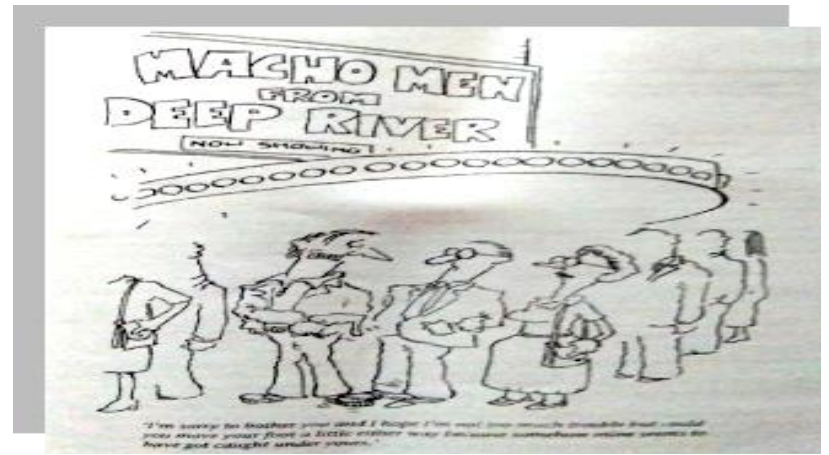

Picture 4.3 taken from An Introduction of Sociolinguistics page 278

After that, they discussed together and were asked to make apology function in accordance with their own cultures seeing the fact that there were a lot of students from different ethnicities.

Situation portrayed in the picture:

There were people queuing for tickets of a movie titled MACHO MAN FROM DEEP RIVER. When these people queiung, a man accidentally stepped on other man foot. This man whose foot stepped said "I'm sorry to bother you and I hope I'm not too much trouble but could you move your foot a little either way because somehow mine seems to have got caught under yours."

\section{Analysis on Apology}

\begin{tabular}{|l|l|l|l|l|l|}
\hline \multirow{2}{*}{ Sentences } & \multicolumn{5}{|c|}{ Strategies used in apology speech act (by Oslhtain \& Cohen) } \\
\cline { 2 - 6 } & $\begin{array}{l}\text { An intensified } \\
\text { expression of } \\
\text { apology }\end{array}$ & $\begin{array}{l}\text { An expression / } \\
\text { acknowledgemen } \\
\text { t of responsibility }\end{array}$ & $\begin{array}{l}\text { An explanation } \\
\text { or account of } \\
\text { the situation }\end{array}$ & $\begin{array}{l}\text { An offer } \\
\text { of repair }\end{array}$ & $\begin{array}{l}\text { of pomise } \\
\text { non } \\
\text { reoccurren } \\
\text { ce }\end{array}$ \\
\hline
\end{tabular}




\section{Permatasari et al., A Study of EFL Students...}

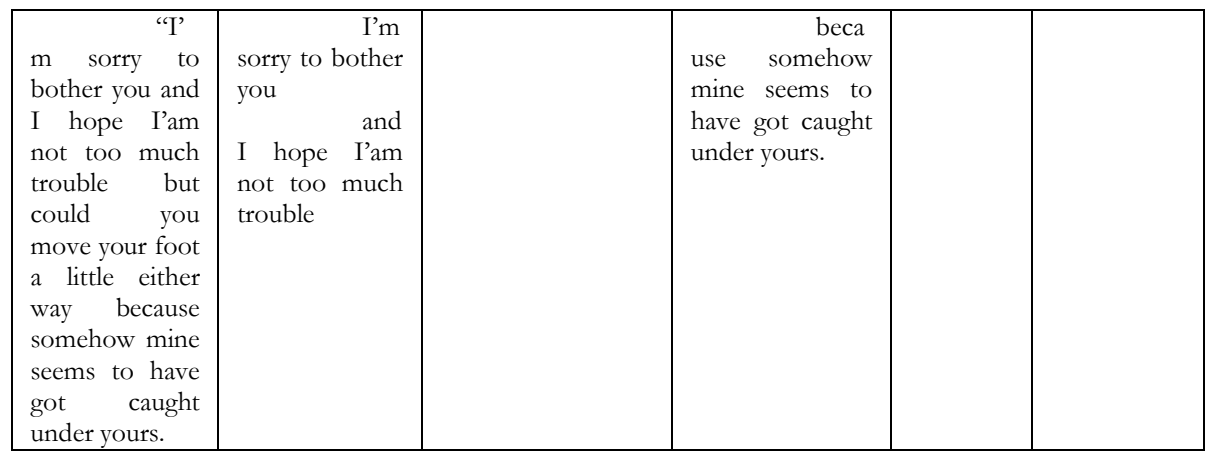

1. In this context, because the action accidentally happened without the hearer's intention, there are no expressions or acknowledgement of responsibility, offer of repair and no promise of non-reoccurrence.

2. The expressions of apology used are:

a. I'm sorry to bother you

b. I hope I am not too much trouble

3. The explanation or account of the situation is:

a. incomplete sentence:

...because somehow mine seems to have got caught under you.

However, the researcher has one type of strategy used in analyzing one speech function: apology. The researcher applied Olshtain and Cohen (1983) apology speech act strategy. Therefore, group discussion which is used as leading activity to raise EFL students' awareness on apology function would be elaborated from one point of view: apology strategy.

\section{Strategies Used in Apology Function}

In this framework, there are five main strategies the researcher used for apology production including (1) expression of apology which itself contains three sub-strategies of expression regret, an offer of apology, and a request for forgiveness; (2) an explanation or account of the situation; (3) an acknowledgement of responsibility, which contains four sub-strategies of accepting blame, expressing self-deficiency, recognizing the other person as deserving apology, and expressing lack of intent; (4) an offer of repair; and (5) a promise of non-reoccurrence (Olshtain and Cohen, 1983 as cited in Tajeddin, Alemi \& Razzaghi, 2014, p. 9). 
Situation 1: Imagine you are travelling on a bus. You put your bag in the rack, but it fell down and hit another passenger.

\begin{tabular}{|c|c|c|c|c|c|c|}
\hline \multirow[b]{2}{*}{$\begin{array}{l}\text { Informa } \\
\text { nt }\end{array}$} & \multirow[b]{2}{*}{ Sentences } & \multicolumn{5}{|c|}{ Strategies used in apology speech act (by Oslhtain and Cohen) } \\
\hline & & $\begin{array}{l}\text { An intensified } \\
\text { expression of } \\
\text { apology }\end{array}$ & $\begin{array}{l}\text { An } \\
\text { expression / } \\
\text { acknowledge } \\
\text { ment of } \\
\text { responsibility }\end{array}$ & $\begin{array}{l}\text { An } \\
\text { explanation } \\
\text { or account } \\
\text { of the } \\
\text { situation }\end{array}$ & $\begin{array}{l}\text { An } \\
\text { offer of } \\
\text { repair }\end{array}$ & $\begin{array}{l}\text { a promise of } \\
\text { non- } \\
\text { reoccurrence }\end{array}$ \\
\hline TY & $\begin{array}{l}\text { Oh, I'm so } \\
\text { sorry! Are } \\
\text { you okay? } \\
\text { (because it } \\
\text { is a } \\
\text { spontaneou } \\
\text { s incident) }\end{array}$ & $\begin{array}{l}\text { Oh, I'm so } \\
\text { sorry! }\end{array}$ & $\begin{array}{l}\text { Are } \quad \text { you } \\
\text { okay? }\end{array}$ & & & \\
\hline WL & $\begin{array}{l}\text { My bad, I } \\
\text { am so sorry. }\end{array}$ & $\begin{array}{l}\text { My bad, I am } \\
\text { so sorry. }\end{array}$ & & & & \\
\hline $\mathrm{MCH}$ & $\begin{array}{lr}\text { I'm really } \\
\text { sorry } & \text { that } \\
\text { just } & \\
\text { happened. }\end{array}$ & $\begin{array}{ll}\text { I'm } & \text { really } \\
\text { sorry. } & \end{array}$ & & $\begin{array}{l}\text { that just } \\
\text { happened }\end{array}$ & & \\
\hline LAU & $\begin{array}{l}\text { I'm so } \\
\text { sorry. Are } \\
\text { you okay? }\end{array}$ & I'm so sorry. & $\begin{array}{l}\text { Are } \quad \text { you } \\
\text { okay? }\end{array}$ & & & \\
\hline SYN & $\begin{array}{l}\text { I am really } \\
\text { sorry, are } \\
\text { you alright? }\end{array}$ & $\begin{array}{l}\text { I am really } \\
\text { sorry }\end{array}$ & $\begin{array}{ll}\text { are } & \text { you } \\
\text { alright? } & \end{array}$ & & & \\
\hline NAN & $\begin{array}{l}\text { Woah... } \\
\text { Sorry mam. } \\
\text { I was going } \\
\text { to put this } \\
\text { bag in the } \\
\text { rack. I didnt } \\
\text { see that } \\
\text { coming, } \\
\text { please } \\
\text { forgive me. }\end{array}$ & $\begin{array}{l}\text { Woah... Sorry } \\
\text { mam } \\
\text { please forgive } \\
\text { me }\end{array}$ & & $\begin{array}{l}\text { I was going } \\
\text { to put this } \\
\text { bag in the } \\
\text { rack. I didnt } \\
\text { see that } \\
\text { coming }\end{array}$ & & \\
\hline
\end{tabular}

\section{ANALYSIS 1:}

1. In this context, because the action accidentally happened without the speaker's intention, there's no offer of repair and no promise of non reoccurrence.

2. The expressions of apology used are:
a. I'm so sorry
b. I'm really sorry
c. Sorry
d. Please forgive me

3. The intensified expressions used are:
a. $\mathrm{Oh}$
b. My bad 


\section{Permatasari et al., A Study of EFL Students...}

c. Woah

4. The expressions / acknowledgement of responsibility are

a. Are you okay?

b. Are you alright?

These two sentences are polite expression to show the addressee that the addresser feels guilty about his or her careless action and cares about the addressee's condition.

5. The explanation or account of the situation is:

a. Complete sentence:

i. I was going to put this bag in the rack.

ii. I didn't see that coming

b. Incomplete sentence:

i. That just happened

Situation 2: Imagine you are the manager of a café. Today you have an interview with a student who wants to a job in the café. However you are half an hour late for the interview because of a meeting. The student is waiting for you in the café.

\begin{tabular}{|c|c|c|c|c|c|c|}
\hline \multirow[b]{2}{*}{$\begin{array}{c}\text { Informa } \\
\text { nt }\end{array}$} & \multirow[b]{2}{*}{ Sentences } & \multicolumn{5}{|c|}{ Strategies used in apology speech act (by Oslhtain \& Cohen) } \\
\hline & & $\begin{array}{c}\text { An } \\
\text { intensified } \\
\text { expression } \\
\text { of apology }\end{array}$ & $\begin{array}{c}\text { An } \\
\text { expression / } \\
\text { acknowledge } \\
\text { ment of } \\
\text { responsibility }\end{array}$ & $\begin{array}{l}\text { An } \\
\text { explanation } \\
\text { or account } \\
\text { of the } \\
\text { situation }\end{array}$ & $\begin{array}{l}\text { An offer of } \\
\text { repair }\end{array}$ & $\begin{array}{l}\text { a promise } \\
\text { of non } \\
\text { reoccurence }\end{array}$ \\
\hline TY & $\begin{array}{l}\text { I'm } \\
\text { extremely } \\
\text { sorry for } \\
\text { making you } \\
\text { wait quite a } \\
\text { long time. } \\
\text { Thank you } \\
\text { for staying. }\end{array}$ & $\begin{array}{l}\text { I'm } \\
\text { extremely } \\
\text { sorry }\end{array}$ & $\begin{array}{l}\text { for making } \\
\text { you wait } \\
\text { quite a long } \\
\text { time. }\end{array}$ & $\begin{array}{l}\text { Thank you } \\
\text { for staying. }\end{array}$ & & \\
\hline WL & $\begin{array}{l}\text { I am sorry } \\
\text { for being } \\
\text { late. My } \\
\text { watch's } \\
\text { battery is } \\
\text { broken and } \\
\text { I have two } \\
\text { meetings } \\
\text { today. Can } \\
\text { we start } \\
\text { now? }\end{array}$ & I am sorry & for being late & $\begin{array}{l}\text { My watch's } \\
\text { battery is } \\
\text { broken and } \\
\text { I have two } \\
\text { meetings } \\
\text { today. }\end{array}$ & $\begin{array}{l}\text { Can we start } \\
\text { now? }\end{array}$ & \\
\hline $\mathrm{MCH}$ & $\begin{array}{l}\text { I do } \\
\text { apologize } \\
\text { for the } \\
\text { inconvenien } \\
\text { t. I had a } \\
\text { meeting } \\
\text { earlier that's } \\
\text { why I come }\end{array}$ & $\begin{array}{l}\text { I do } \\
\text { apologize } \\
\text { for the } \\
\text { inconvenien } \\
\text { t. }\end{array}$ & $\begin{array}{l}\text { that's why I } \\
\text { come late. }\end{array}$ & $\begin{array}{l}\text { I had a } \\
\text { meeting } \\
\text { earlier }\end{array}$ & & \\
\hline
\end{tabular}




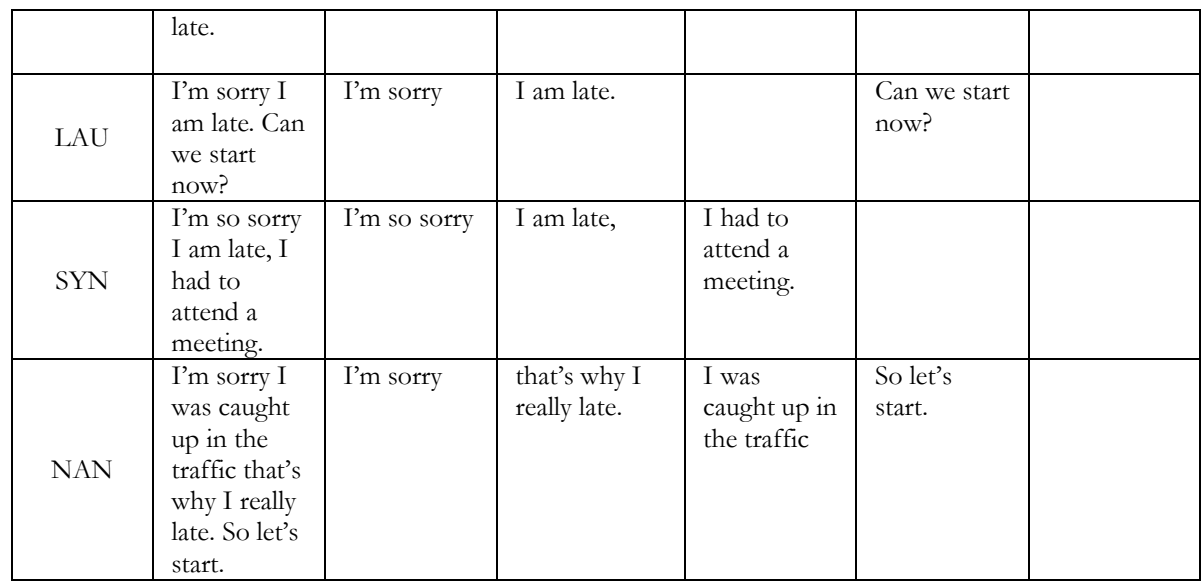

\section{ANALYSIS 2:}

1. In this context, the addressers violate the punctuality in making an appointment with his or her candidate of worker. From the corpus gathered, while dealing in such context, some of the informants tried to defend themselves by explaining the situation. Some of them preferred not give any explanation.

2. All informants do not give a promise of non reoccurrence.

3. The expressions of apology used are:

i. Sorry

ii. I do apologize

4. The expression / acknowledgement of responsibility are in the form of:

i. incomplete sentence:

a. for making you wait quite a long time

b. for being late

c. that's why I come late

d. that's why I really late

ii. complete sentence:

a. I am late

5. The explanation or account of the situation in the form of complete sentence:

a. Thank you for staying.

b. My watch's battery is broken and I have two meetings today.

c. I had a meeting earlier 


\section{Permatasari et al., A Study of EFL Students...}

d. I was caught up in the traffic

6. Three informants gave an offer of repair in the form of complete sentence:

a. Can we start now?

b. Let's start now.

\section{B. Group discussions in teaching materials preparation: as topic-oriented activity}

In preparing teaching materials, a lecturer must present an issue which attracts students' interests. This issue or related topic which is familiar with their background knowledge will lead them to positively engage and participate in the classroom. In this case, topics or issues in the sense of students' cultural norms like food, dances, custom, and songs from many ethnicities. Then, the lecturer's duty is to bring and adjust these students to the target culture. In dealing with the topics, EFL students prefer to do group discussion to discuss the cultural border between their own and the world of the target language in relation with speech acts function. Considering there are two knowledge that are required to be acquired by EFL students: linguistic and pragmatic knowledge, Watts' (2010), Alemi \& Tajeddin (2013), Jalilifar (2009) findings showed that EFL learners did not have sufficient pragmatic knowledge. The most common function EFL students use in daily life is apology which they lack of knowledge. Thus, group discussion: sharing ideas, experience with classmates will lead EFL students to understand the practices of apology function (Lave\&Wenger, 1991). The following will be the elaboration of two types of group discussion which enhance EFL learners' awareness of apology function.

First, politeness for apology became one topic for discussion. Knowing that TY, WL live in Indonesia, they seldom use apology pattern to NS or friends who speak English. They only speak or express the word sorry when they do something wrong whether he or she is older or younger than them for apology function. The recognition of social power gained when TY and WL discussed with their friends who live abroad or the NS lecturer who teach them. 
I feel that I found it was quite difficult for me to adjust with it in the beginning because I used to say sorry a lot especially to people with higher social power (professor or teacher) and here, a single "I do apologize" is enough. Because unlike in Indonesia, everything here is straight to the point (TY, 24/03/2017).

Group discussion with classmates who came from many countries like American, Italian, and Germany about apology function in term of politeness made TY more aware of addressing apology expression toward young, same age or even older people. Similar to TY, WL gained more understanding how to address apology function by doing discussion with the natives when she encountered CCU course.

Natives whom I speak to tanght me about the difference use of I am sorry, I do apologize, I feel sorry about... for apology (WL, 28/08/2017).

WL regarded that by having discussion with the Natives as an effective way to raise EFL students' awareness on apology function. The natives face the real world and performing those two functions in their daily life. Thus, by having discussions with the natives teach WL how to express apology function and address it properly. Moreover, being linguistically polite involve speaking to people appropriately in the light of relationship between speaker and hearer. Making decisions about what is or is not considered polite in any community of practice therefore involves assessing social relationships along the dimensions of social distance or solidarity, and relative power or status (Laver, 1981, p. 285). Thus, gaining linguistic and pragmatic competence is required to understand and practice apology function well.

Second, culture festival as a form of cultural activity enhanced EFL learners' awareness on apology. Culture festival is one type of visible culture that is apparent to anyone and can be discussed and explained relatively easily (Hinkel, 2018, p. 5). Similarly, culture festival was chosen as one favorite activity which provided insights from EFL students to be a cultural sensitive person. When culture festival is held, EFL students had to pick one ethnicity from Indonesia or other countries and dress up like them. What is more attractive, they had to walk around the campus field 


\section{Permatasari et al., A Study of EFL Students...}

and asked or discussed or even responded their classmates who wore the other costumes and prepared some situations of speech act functions. Likewise, LAU who loved culture festival as a leading discussion to raise her awareness toward apology function.

I would prefer to choose an activity which engage students' creativity and team-working like culture festival. We dressed up like people from different countries but we weren't allowed to dress up like Javanese people. Then, we did something interesting. We made conversation with certain situation and we listened to each other stories of our own costumes. (LAU, 25/10/2017).

The same idea came up from NAN about culture festival. He concluded that by participating in culture festival, he had no choice to work and gather with his classmates instead of doing individual working. Therefore, he gained a lot of experience, knew more about the use of speech act function and different cultural background of his classmates and realized that culture in the world is varied.

\section{Role Playing in Teaching Materials Preparation: As Authentic Materials Selection}

The second choice of CCU learning activities that contribute EFL students' awareness on apology is role playing. A lecturer should consider engaging activities instead of delivering the materials that keep the students in passive state. Therefore, role play, as an active teaching strategy, creates positive elements of enjoying learning process and gaining knowledge, when implemented successfully and selecting authentic materials (Erturk, 2015; McSharry\&Jones, 2000). In the same way, role play can enhance students' interests in learning the materials. The same idea came from AR who chose role play as the attractive CCU learning activity which is engaging and fun.

Role playing a certain culture is another fun activity because everyone in the class love performances, so it's an engaging yet fun activity for the students to grasp the issue especially when we talk about speech act functions like saying thanks, making apology (AR, 11/10/2017).

She felt that role play is a good way to grab students' attention to focus on speech act functions. By doing role play, EFL students directly practice the dialogue from script-reading and there 
will be communication between the speaker and hearer. In the same time, they learn to express apology function and respond it as well. Thus, she thought that role play is the most effective way to enhance her skills and raise awareness on apology function.

Then, role play raises the link between the learning situation and the real world (Thiagarajan 2003 as cited in Greco 2009 p. 163). Similarly, role playing is viewed and has proven to be effective way to bridge students to their real world. Meaning that, when they do role playing they practice what they face in the real life. Moreover, RI has the same idea about role playing when she could share her understanding about other cultures with her classmates.

By doing a role play, we not only understand cultures from other countries but also put it into practice to share the knowledge to others. Role playing about Javanese vs Korean: apology. Javanese prefer saying a lot sorry everytime they make mistakes. Besides, Korean only remark for big mistakes then they say sorry. (RI, 28/08/2017).

Role playing on apology function also promote interaction among players: those who are in the dialogue (Van Ments 1989 as cited in Greco 2009 p. 163). When RI did role playing about Javanese vs Korean, she did interaction with her partner talking about what Javanese and Korean custom of asking for apology. Therefore, engagement among students who came from many ethnicities was increased through role playing (Clark \&Choi, 2005, Wishart et.al., 2007 as cited in Greco 2009 p. 163).

\section{To what extent do CCU learning activities contribute toward EFL students' awareness on apology?}

Based on the analysis above, CCU learning activities which contributed toward EFL students' awareness on apology were group discussion and role playing. To begin with, the students found group discussion as learning strategy to make them aware of expressing apology function. By doing group discussion, EFL students gain more knowledge about others' cultures and in the same time they maintain good relations between others (Holmes, 1990). In addition, doing group discussion made EFL students recognize their position when they talk to each other: the social distance (the relationship between the speaker and the hearer), 


\section{Permatasari et al., A Study of EFL Students...}

social power (the rank between the addressor and addressee) and imposition (description of the situation) (Brown \& Levinson, 1987; Searle, 1975). Likewise, EFL students should be aware of behavior, intonation pattern, choice of expression used which are appropriate in their own speech community with different cultural background (Peterson \& Coltrane, 2003; Flood, 2003). Hence, the success of making communication with both native or non native speakers is acquiring two kinds of competence: linguistic and pragmatic (Cortazzi \& Jin, 2008; Goh \& Kwah, 1997; Harvey, 1985; Rao, 2002; Leung, 2005).

For strategies used in apology, EFL students were able to differentiate the expressions of "sorry", "please forgive me" and intensifiers like "very" and "really" (Olshtain \& Cohen (1983); Olshtain (1989); Eslami Rasekh \& Mardani, 2010)). The findings on strategies used in apology showed that EFL students used an expression of apology like "sorry" with intesifiers like "so", "really", "please forgive me", and "I do apologize. Also, they stated an expression of responsibility like "are you okay?" or "are you alright?" (in complete sentence) and "....for making you wait quite long time”, “....for being late”, “....that's why I come late”, “...that's why I really late (in incomplete sentence). Moreover, EFL students expressed an explanation on the situation by saying "I was going to put this bag in the rack", "I didn't see that coming", "thank you for staying.", "my watch battery is broken and I have two meetings today", "I had a meeting earlier", "I was caught up the traffic" (in complete sentence) and "...that just happenned" (in incomplete sentence). At last, some EFL students stated an offer of repair by saying "can we start now?" and "let's start now". However, none of students used a promise of non reoccurence. Thus, group discussion as one of cross cultural learning activity contributed toward EFL students' awareness on apology function in form of a leading activity which foster and enhance students' awareness by doing discussions among students with varies cultures and ethinicities in certain situations using certain speech acts in this case apology and its strategies.

In the second, group discussion as topic-oriented activity was resulted in two findings. First, EFL students were discussed more on politeness for apology. They became more aware of 
addressing those two functions whether to same age, younger or older people. Besides, TY gained more knowledge about politeness when she met her classmates which came from different countries where English is as Foreign language. Similarly, discussion with the natives which WL did strengthen the way she communicates and address toward people she is going to talk. Then, discussion on culture festival created not only recognition of cultural and ethnicity varieties but also awareness of communicating through different situation using different speech functions.

\section{CONCLUSION AND IMPLICATION}

Last of all, role playing as authentic material selection regarded to be second way of enhancing EFL students' awareness on apology. For instance, AR and RI found that role playing was able to attract students' attention by creating the script of the situation, practising the script-reading and the existence of communication between the speaker and hearer of certain situations with apology function.

Language and culture are inseparable meaning that they cannot be separated and relate one to another. Thus, when teaching a foreign language cannot be separated from teaching its cultural and social norms. When it comes to EFL students' awareness on apology and request functions through Cross Cultural learning activities, it is a must for the lecturer to find the most attractive activities which engage, enhance, raise EFL students' interest and awareness. Hopefully, the findings of this study will help EFL lecturers to give more attention to students' pragmatic competence, raise their awareness on social cultural norms of speech acts realization in this case apology and request functions concerning politeness values are just as essential as acquiring linguistic competence.

\section{REFERENCES}

Abolfathiasl, H., \& Abdullah, A. N. (n.d.). pragmatic consciousness-raising activities and EFL learners' speech act performance of 'making suggestions'. Journal of Language Teaching and Research, 6(2), 333-342. 


\section{Permatasari et al., A Study of EFL Students...}

Austin, J. L. (1962). How to do things with words. Oxford: Clarendon Press.

Bardovi-Harlig, K. \& Hartford. (1993). Learning the rules of academic talk: a longitudinal study of pragmatic change. Studies in Second Language Acquisition, 15, 279-304.

Bergman, M. L., \& Kasper, G. (1993). Perception and performance in native and nonnative apology. In G. Kasper \& S. Blum-Kulka (Eds.), Interlanguage Pragmatics, 82-107. Oxford: Oxford University Press.

Brown, P., \& Levinson, S. (1987). Politeness: Some universals in language usage. Cambridge: Cambridge University Press.

Cakir, I. (2006). Developing cultural awareness in foreign language teaching. Turkish Online Journal of Distance Education, 7(3), p. 154-161, ISSN 1302-6488.

Cohen, A. (2008). Teaching and assessing L2 pragmatics: What can we expect from learners? Language Teaching,41, 213-235.

Cook, M. \& A. J. Liddicoat. (2002). The development of comprehension in interlanguage pragmatics: The case of request strategies in English. Australian Review of Applied Linguistics, 25(1), 19-39.

Cortazzi, M., \& Jin, L. (2008). English teaching and learning in China. Language Teaching, 29(02), 61-80.

Dai, L. (2011). Practical Techniques for Cultural-based Language Teaching in the EFL Classroom. Journal of Language Teaching and Research, 2(5), 1031-1036. doi:10.4304/jltr.2.5.1031-1036.

Domakani, M.R., Hashemian, M., \& Mansoori, S. (2013). Pragmatic Awareness of the Request Speech Act in English as an Additional Language: Monolinguals or Bilinguals. RALS, 4(1), 88-109.

Ellis, R. (1994). The studies of second language acquisition. Oxford: Oxford University Press.

Enslen, Todd. Acquisition of Greetings, Requests, and Apologies by Japanese Students in an ESL vs. an EFL Environment, 連絡先：テ980-8576 宮城県仙台市青葉区川内41 東北大学高等教育開発推進センター enslen@he.tohoku.ac.jp pp.187-200. 
Fadeeva \& Kalinin. (2012). The Importance of Cross Cultural Understanding for ESL Students, УНИВЕРСИТЕТ им. В.И. ВЕРНААСКОГО, 4(42), 144-151.

Fielding, M. (2006). Effective communication in organizations (3rd ed.). Cape Town: Juta \& Co. (Pty) Ltd.

Flood, J. (2003). Handbook of research on teaching the English language arts. Mahwah, New Jersey: Lawrence Erlbaum Associates, Inc., Publishers.

Gibbs, G. R., (2007). Analyzing qualitative data. In U. Flick (Ed). The Sage Qualitative Research Kit. London: Sage.

Goh, C., \& Kwah, P. F. (1997). Chinese ESL students' learning strategies: A look at frequency, profi-ciency and gender. Hong Kong Journal of Applied Linguistics, 2(1), 39-53.

Gumperz, J. J., \& Cook-Gumperz, J. (1982). Introduction:

Language and the communication of social identity.

Cambridge: Cambridge University Press.

Harvey, P. (1985). A lesson to be Learned: Chinese approaches to language learning. ELT Journal, 39(3), 7-9.

Holliday, A. (1994). Appropriate methodology and social context. Cambridge University Press.

Hymes, D. (1975). Foundations in sociolinguistics an ethnographic approach. America: Weidner Associates,Inc., Cinnaminson, NJ.

Jiang, W. (2000). The Relationship Between Language and Culture, ELT Journal, 54(4), 328-334.

Kasper, G. (1996). Introduction: Pragmatics in SLA. Studies in Second Language Acquisition, 18, 145-148.

Kasper, G. (1997). Can pragmatic competence be taught? Network \#6) [HTML document]. Honolulu HI: University of Hawaii at Manoa, Second Language Teaching and Curriculum Center. Retrieved Kasper, G. and Rose, K. (2002. Pragmatic Development in a Second Language. Malden: Blackwell Publishing.

Krippendorff, K. (2004). Content analysis: An introduction to its methodology (2nd ed.). Thousand Oaks: Sage. 


\section{Permatasari et al., A Study of EFL Students...}

Kurdghelashvili, T. (2015). Speech acts and politeness strategies in an EFL classroom in Georgia. World Academy of Science Engineering and Technology, 9(1), 306-309.

Lee, P. (1998). Cross-cultural Awareness Raising in TEFL Pre-service Preparation Courses. MA dissertation in Applied Linguistics, the University of Birmingham.

Lee, P. (2000). Cross-cultural Awareness Raising in TEFL Preservice Preparation Courses, 5(1), 17-36.

Leung, C. (2005). Convivial communication: recontextualizing communicative competence. International Journal of Applied Linguistics, 15(2), 119-144.

Mackey, A., \& Gass, S. (2005). Second language research: Methodology and design.Mahwah, NJ: Lawrence Erlbaum. Mayring, Philipp (2000, June). Qualitative content analysis [28 paragraphs]. Forum Qualitative Sozialforschung / Forum: Qualitative Social Research [On-line Journal], 1(2), Art. 20. Available at: http:/ /www.qualitative-research.net/fqstexte/2-00/2-00mayring-e.htm [Date of access: October 5, 2004].

Mayring, P. (2002). Einführung in die qualitative Sozialforschung, Eine Anleitung zu qualitativem Denken (5th ed.). Weinheim: Beltz.

Mizne. C. A. (1997). Teaching Sociolinguistic Competence in the ESL Classroom: A College Scholars Project. Retrieved March 22, 2017 in

http:/ / trace.tennessee.edu/cgi/viewcontent.cgi?article $=101$ 9\&context=utk_interstp2

National Standards in Foreign Language Education Project. (1996). Standards for foreign language learning in the 21st century. Yonkers, NY: Author.

Olshtain, E., \& Cohen, A. (1983). Apology: A speech act set. Sociolinguistics and Language Acquisition, 18-35.

Peterson, E., \& Coltrane, B. (2003). Culture in second language teaching [Electronic Version]. Center for Applied Linguistics. Retrieved March 22, 2017 from http://www.cal.org/resources/Digest/0309peterson.html

Porter, R. E., \& NANovar, L. A. (1991). Basic principles of intercultural communication. In L. A. NANo-var \& R. E. 
Porter (Eds.), Intercultural communication: A reader.

Boston, MA: Wadsworth Cengage Learning.

Qorina, D. (2012). Realization of apology strategies by English department students of Pekalongan university language, circle Journal Of Language And Literature, 7(1), 93-105.

Rao, Z. (2002). Chinese students' perceptions of communicative and noncommunicative activities in EFL classroom. System, 30(1), 85-105.

Robinson, G. L. N. (1985). Culture bound. Cambridge University Press.

Rose, K. R. (1999). Teachers and students learning about requests in Hong Kong. Culture in second language teaching and learning. Ed. E. Hinkel. Cambridge: Cambridge University Press. 167-180.

Sardi, C. (2002). On the Relationship between Culture and ELT. Studies About Languages (3), 101-107.

Searle, J. R. (1969). Speech acts: An essay in the philosophy of language. Cambridge, UK: Cambridge University Press

Seliger, H. W., \& Shohamy, E. (1989). Second language research methods. Oxford: Oxford University Press.

Sifianou, M. (1999). Politeness phenomena in England and Greece. A crosscultural perspective. Oxford: Oxford University Press.

Smith, E. L. (1985). What is the Difference and What Difference Does the Difference Make. In Forum vol.22.

Tanaka, N. (1991). An investigation of apology: Japanese in comparison with Australian. Maikai Daigaku Gaikokugo Gakubu Ronsbu, 4, 35-53.

Titscher, S., Meyer, M., Wodak, R., \& Vetter, E. (2000). Methods of text and discourse analysis (Bryan Jenner, Trans.). London: Sage.

Trosborg, A. (1995). Interlanguage pragmatics: Requests, complaints, and apologies. Berlin: Mouton de Gruyter.

Wijayanto, A. (2013). The Emergence of the Javanese Sopan and Santun (Politeness) on the Refusal Strategies Used by Javanese Learners of English. The Internet Journal Language, Culture and Society, 36, 34-47. Retrieved from http://aaref.com.au/en/publications/journal/

Wolfson, N., Marmor, T., \& Jones, S. (1989). Problems in the comparison of speech acts across cultures. In S. Blum-Kulka, J. 


\section{Permatasari et al., A Study of EFL Students...}

House \& G. Kasper (Eds.), Cross-cultural pragmatics (pp. 174-196). Norwood, NJ: Albex.

Yin, R. K. (2003). Case study research: Design and Methods (2nd ed.). Thousand Oaks, CA: Sage.

Yin, R. K. (2003). Case study research, design and methods (3rd ed., vol. 5). Thousand Oaks: Sage.

Youssef, H. Z. (2009). The Relationship Between Cross-Culture Communication Activities and Student Motivation in Studying Second Language. Retrieved March, 22, 2017 from http:/ / files.eric.ed.gov/ fulltext/ED511897.pdf

Zacharias, N. (2012). EFL students' understanding of their multilingual English identities. Electronic Journal of Foreign Language Teaching, 9(2), 233-244.

Zhao, Y., \& Throssell, P. (2011). Speech act theory and its application to efl teaching in china. The International Journal Language Society and Culture, 32, 88-95. Retrieved from www.educ.utas.edu.au/users/tle/JOURNAL/

Zayed, M. (2014). Jordanian EFL Teachers' and Students' Practice of Speech Acts in the Classroom. International Journal on Studies in English Language and Literature (IJSELL), 2(5), pp.110, ISSN 2347-3126 (Print) \& ISSN 2347-3134 (Online) www.arcjournal.org. 